This item is the archived peer-reviewed author-version of:

Regional parliaments in the EU multilevel parliamentary system

\title{
Reference:
}

Bursens Peter, Högenauer Anna-Lena.- Regional parliaments in the EU multilevel parliamentary system

The journal of legislative studies - ISSN 1357-2334 - 23:2(2017), p. 1-17

Full text (Publisher's DOI): https://doi.org/10.1080/13572334.2017.1329984

To cite this reference: https://hdl.handle.net/10067/1432800151162165141 


\section{Regional Parliaments in the EU Multilevel Parliamentary System}

Bursens, Peter and Högenauer, Anna-Lena

Published in Journal of Legislative Studies, 2017, 23()2, DOI: 10.1080/13572334.2017.1329984

\section{Abstract}

European integration has created a multilevel political system that is dominated by executive actors. Despite the increasing competences of the European Parliament, a growing EU-awareness of national assemblies and an emerging attention of regional parliaments for EU affairs, the EU polity still lacks a sound parliamentary representation. As the EU presents itself as a representative democracy, the current set-up raises questions from the perspective of democratic legitimacy. The establishment of multilevel parliamentarianism may be part of the remedy. This introduction focuses on the position that regional parliaments take in such a European multilevel parliamentary system. We address three relevant questions: what roles do regional parliaments take up in terms of legislation, scrutiny and networking; to what extent are they empowered by the Lisbon Treaty and what explains the variation in their activities. We develop hypotheses that are to varying degree addressed by the contributions in this special issue. 


\section{Introduction}

The European Communities originally started with a set of institutions and a power balance that were both heavily tilted in favour of executives. As the powers of the EU expanded over time, the democratic and legitimate nature of its decision-making raised increasing concern. This led to the strengthening of the European Parliament, but also to the growing recognition of subnational levels of government, and thus to the gradual emergence of an EU system of multi-level governance. But do more levels of government automatically lead to more democracy?

Even today, EU multi-level law- and policy-making relies heavily on European and national level executives: overall policy guidance is set by the heads of state and government of the member states in the European Council, specific proposals are developed by the European Commission, and the stronger one of the two European legislators - the Council of Ministers - is composed of national (and occasionally subnational) ministers. In addition, a growing number of agencies and institutions, such as the European Central Bank, are granted substantial autonomous decision-making powers while legislation is increasingly replaced by executive measures (such as delegated acts) and soft coordination instruments (e.g. within the Europe 2020 agenda) in which executive institutions are dominant actors. However, if one accepts that parliamentarisation is an important part of the response to the European democratic deficit (Follesdal \& Hix, 2006), and that Europe does not have one unified demos, but multiple national/regional demoi (Nicolaïdis, 2013; Cheneval \& Schimmelfenning, 2013), then national - and in at least eight member states also regional - parliaments come into the picture (Weiler, 2012).

The question of how national parliaments cope with European integration has received growing attention in recent years. Scholars have analysed national parliaments' activities, institutional strength, institutional adaptation, resources and performance (for recent contributions, see e.g. Cooper, 2012; Raunio, 2011; Winzen, 2012; Hefftler et al., 2015, Auel \& Christiansen, 2015; Bellamy \& Kröger, 2016; Sprungk, 2016). By contrast, academics have largely ignored the topic of regional parliaments, except for single country-studies (Abels, 2013, Carter \& McLeod, 2005) and some pioneering comparative work (Boronska-Hryniewiecka, 2013b; Abels \& Eppler, 2015). These studies almost exclusively deal with the aggregate level, with Schneider et al. (2014) as a notable exception. The limited attention for regional parliaments may seem surprising considering the extensive attention for regional governments, and especially since eight member states contain regional parliaments with legislative powers (Germany, Austria, Belgium, the United Kingdom, Spain, Italy, Portugal and Finland). One can think of several reasons for this lack of attention. First, comparative research into regional parliaments is challenging, as it requires detailed knowledge not only of the European and national, but also of the regional contexts (Ladrech, 2015). In addition, regional parliaments have only been recognized as 
formal participants in EU policy-making since the Treaty of Lisbon in 2009. Finally, regional assemblies vary substantially regarding the level of EU competencies, which makes comparative research rather demanding.

Nevertheless, the Treaty of Lisbon has acted as a wake-up call for regional parliaments as it triggered various institutional and procedural reforms designed to improve the scrutiny of EU affairs at the subnational level. The aim of this volume is therefore to examine the role regional parliaments take up in the EU policy-making arena. This includes an examination of the functions they fulfil, and hence the activities they deploy, in EU policy-making, their empowerment in the wake of the Lisbon Treaty and the factors that can explain variation in activities and power. From the scarce literature so far, we already know that regional parliaments' activities and power vary a lot. The articles in this volume will add more detailed and systematic empirical knowledge to this. To frame these contributions, the introduction first reviews the ways in which regional parliaments are important for a democratic EU, next it discusses the channels of participation and influence in EU politics that are available for regional parliaments, and finally, it outlines the three key questions that will be investigated in this special issue.

\section{A Role for Subnational Parliaments in EU Democracy?}

The nature of democracy in the EU is a much debated topic among EU scholars. Different views are rooted in different conceptualisations of the EU. We agree with those who argue that the EU has moved beyond a mere international organization or regulatory agency controlled by its member states (cf. Follesdal \& Hix, 2006) and that it also contains supranational (if not federal) characteristics. We thus see the EU as a proper political system, composed of multiple layers. Both its functioning and legitimation are therefore multilevel as well. One way to legitimise a polity is through representation. Crum and Fossum (2009) argue convincingly that especially parliamentary representation is the most suitable way of ensuring political equality and public deliberation, which are crucial criteria for democratic legitimacy (see also Bellamy \& Kröger, 2012a). Moreover, the EU treaty itself (Art. 10(2) TEU) defines the EU as a representative democracy (Bellamy \& Kröger, 2012b) which thus raises expectations regarding the role of parliaments in the EU.

Yet, it is exactly in the area of parliamentary representation that arguably the most important democratic shortcoming of the EU is to be found. Even after the implementation of the Lisbon Treaty, the EP is still deprived of legislative powers in several domains that belong at least partially to EU competences and, of course, the EP still lacks the right to initiate legislation (Corbett et al., 2016). In addition, several authors contend that parliamentarisation at the EU level alone is not sufficient and that at least part of the solution is therefore (also) situated at the level of the member states (cf. 
Maurer, 2002). Thus, Weiler (2012) argues that the EU will ultimately need to base its legitimacy on national democratic institutions, including national parliaments while Cooper $(2012 ; 2013)$ uses the concept of virtual third chamber or even tricameralism to call for the activation of national parliaments. Likewise, Puntscher Riekman and Wydra (2013) add the national level ('representation of the parts') to the EU level ('representation of the whole') when it comes to parliamentary representation.

Nevertheless, domestic parliaments struggle in the European multi-level context. Bellamy and Kröger (2012a; 2012b) argue that national parliaments are limited in their capacity to serve the representative role. National parliaments and national parties are left with less policy space as competencies have been transferred to the European level. They also have a decreasing policy repertoire at their disposal due to the single market dominance at the EU level, while supremacy and direct effect of EU laws combined with an activist Court of Justice increasingly limit the national parliaments' and parties' discretion. All this results in a decreasing capacity to offer voters alternative policy options. In addition, national parliaments often lack ex ante scrutiny of national governments' the bargaining positions in EU policies as they suffer from informational asymmetries. Moreover, the increasing use of mechanisms such as the open method of coordination (OMC) exclude national parliaments from participation in much of EU policy-making.

The reaction of national parliaments has been to enhance their institutional capacity to seek more EU related information, and to increase scrutiny of EU policies (e.g. through establishing European Affairs committees and by activating the Early Warning System). Hence, despite the shortcomings of national parliaments, what is put in place in the EU context can be considered as an emerging multilevel parliamentary system, which comes down to a balancing act between direct representation of citizens (through the European Parliament) and indirect representation of its constitutive units (Warleigh, 2003). This perspective has been taken by Hurrelmann (2007), by Lord and Pollak (2010), who have coined the term of compound representation, and by Crum and Fossum (Crum \& Fossum 2009; 2012, Crum 2015), who have proposed the notion of the Multilevel Parliamentary Field in this respect.

There is still an element missing, however, as all these approaches hardly ever include the role that regional parliaments can play in the EU multilevel parliamentary system. This is remarkable as a growing number of EU member states is confronted with an evolution towards internal multilevel governance, be it federal states (Germany, Austria, Belgium), quasi-federal or devolved states (Italy, Spain, the UK) or asymmetrically decentralized states (Portugal and Finland). The regional constitutive entities of these member states have directly elected legislatives, which enjoy varying but often substantial competencies in a large set of EU policies (Cloots et al., 2012), making these regional 
parliaments also largely responsible for the implementation of EU directives (Treib, 2014). For these member states, a multilevel parliamentary system also comprises the regional legislatives. Here, we disagree with Crum (2015) who argues that national democracy is qualitatively different form subnational or European democracy only allowing for institutional and sociological exceptions (e.g. UK, Belgium, Spain). On the contrary, our analysis does include long-standing federations like Germany or Austria should be included as in both countries, the constitutions foresee that all competences are by default regional competences, unless the constitution states otherwise (Art. 15(1) B-VG, 25. Juli 2012; art. $30 \mathrm{GG}, 23.12 .2014)$.

In short, despite their relevant position in the EU polity, regional parliaments have hardly been discussed in scholarly work on representation as part of democratic legitimacy. For instance, the recent 2013 Journal of European Integration special issue on representation in the EU, nor the 2015 West European Politics or the 2016 Comparative European Politics special issues on parliaments in the EU pay attention to regional parliaments. It is the aim of this contribution to expand the research agenda by incorporating the regional parliamentary level in the analysis of multilevel parliamentarianism in the EU.

\section{Regional Parliaments in EU Affairs}

The following guiding research question is raised: What roles do regional parliaments take up in EU policy-making? To answer this, we depart from the different functions that national parliaments can assume in the EU. According to Sprungk (2013) national parliaments take up new roles in the multilevel environment that has been established by European integration. She mentions gatekeeping, scrutinizing and networking functions. The first refers to the Early Warning System (EWS) which enables national parliaments to make the European Commission reconsider proposing legislative acts when these are considered breaching the subsidiarity or proportionality principles. The scrutinizing role points to the classic control function of parliaments, while the networking role points to the horizontal and vertical relations between parliaments. Regional parliaments are equally involved in the EWS, either through the second chamber or by themselves, they have the possibility to control regional executives when the latter take part in national EU policy coordination, and they are part of the broader network of legislatives. Hence, what Sprungk describes for national parliaments also accounts for regional assemblies, be it to varying degrees depending on their position in the constitutional framework. A similar list of functions is presented by Abels (2013) who distinguishes between two types of functions. Type 1 consists of legislative, control, budget and elective functions. Abels stresses that the first three are heavily affected by European integration: national parliaments need to 
accommodate the traditional way of law-making and scrutinizing to the European multilevel context: their role shifts from initiating new legislation towards implementing EU legislation and from scrutinizing national executive measures to controlling national executives' behaviour at the EU level. Again, depending on the domestic constellations, regional parliaments to varying degrees have become responsible for implementation of EU laws and for scrutinizing EU policy coordination. Abels' type 2 encompasses communication and networking, the latter coinciding with Sprungk's third dimension, and hence applicable to both the national and the regional levels. Control and networking are also the two dimensions in Högenauer's (2015) analysis of the Scottish Parliament. She argues that domestic parliaments should adapt and enhance participation and scrutiny of national EU policymaking and should invest in interparliamentary relations within the EU multilevel parliamentary system. In the following we take the encompassing concept of parliamentary scrutiny to list the opportunities regional parliaments have, to get involved in EU policy-making in terms of legislative gatekeeping, scrutinizing and networking.

In practice, regional parliaments have three major ways of participating in EU policy-making: they can try to influence the policy-making activities of EU institutions (legislative function), attempt to control how their national and regional governments act in EU policy-making (scrutiny function) and seek to network with other legislative or executive actors in the multilevel environment. The networking function is a hybrid one that can be used to support the other two functions. For example, parliaments can build coalitions with other actors to improve their ability to influence legislation (legislative function) or to gather information that they can use to control their executives (scrutiny function).

On the European level, regional parliaments have two options. Firstly, a limited number of representatives of regional parliaments sit on the Committee of the Regions (CoR). The CoR is an advisory committee in EU policy-making that has to be consulted on a wide range of issues and that has the right to adopt opinions on its own initiative in the remaining policy areas. Under the Treaty of Lisbon, it furthermore gained the right to bring cases for annulment of laws on grounds of subsidiarity before the Court of Justice. However, in May 2013 only about 10 percent of the members of the Committee of the Regions represented regional parliaments with legislative powers (Högenauer et al., 2016), and at the time of writing (2016) that number was at 7 percent. The rest represent local councils, regional executives etc., which means that even in the CoR parliamentary concerns only play a marginal role.

Secondly, the Treaty of Lisbon allows regional parliaments to participate in the new EWS, albeit only in collaboration with their national parliament. The EWS - defined in the Protocol on Subsidiarity and Proportionality - allows each national parliament to review EU legislative proposals for conformity 
with the principle of subsidiarity within an eight-week period after publication. Each national parliament has two votes and, in the case of most bicameral parliaments, each chamber has one vote. This means that regional parliaments have a direct or indirect role to play in the EWS. If domestic parliaments amounting to more than one third of all votes adopt "reasoned opinions" detecting a breach of subsidiarity, the European Commission must review its proposal.

While this new opportunity has triggered much interest among national parliaments and several reforms in regional parliaments (Vara Arribas \& Högenauer, 2015), its importance should not be overstated. The level of influence that regional parliaments can wield under the EWS is limited by its features. Firstly, domestic parliaments cannot force European institutions to withdraw a proposal or even just to amend it. Secondly, the tight deadline of eight weeks makes it difficult for national parliaments to adopt a reasoned opinion. For regional parliaments, this period is even shorter, as they must give the national parliament time to process its opinion. Next, the focus of the EWS is rather narrow: technically all objections have to be couched in terms of subsidiarity. In addition, the threshold for votes is relatively high (so far, the required number of votes has only been reached in two cases). Finally, national parliaments are only rarely obliged to take the views of regional parliaments into account (Crum, 2015): the Protocol on the application of the principles of subsidiarity and proportionality leaves the consultation of regional parliaments to the discretion of national parliaments. As Vara Arribas (2015) points out, some parliaments like the British or Spanish only mention regional opinions, if they themselves also adopt a reasoned opinion. Otherwise, regional parliamentary opinions are not necessarily passed on to the EU institutions.

Overall, regional parliaments thus only benefit from a limited range of options if they wish to influence legislative proposals of the European Commission. With respect to other than legislative policy measures that equally affect regional competencies no formal participation of regional parliaments at all is envisaged by the EU legal framework. This is a remarkable observation given the relevance of for instance the Europe 2020 agenda in the areas of social, economic and environmental policies, which often belong to regional policy portfolios.

The other option for regional parliaments is to focus on controlling the position of the regional executive within the domestic EU policy coordination. In those countries that have regional parliaments with legislative powers, the regional executives would normally either can attend meetings at different levels in the Council of Ministers, or they would at least be consulted during the coordination stage of member state positions. However, regional governments benefit from two advantages over regional parliaments in this respect. Firstly, they have an information advantage, as they attend European negotiations or national coordination meetings, whereas parliaments have to 
rely on minutes or reports. Secondly, regional governments benefit from the fact that the complex negotiation and coordination systems allow them to disguise to some extent their precise position, what exactly they agreed to give up in return for what other concession and how quickly they were willing to give in. Thus, in the same way in which national governments can blame other member states or "Europe" for unpopular decisions, regional governments can blame "Europe", other member states and the national government and potentially even other regional governments.

Nevertheless, it is worth noting that regional parliaments have a range of options at their disposal to control regional governments in EU affairs: they can request information and explanation via parliamentary questions, they can organize debates on controversial issues and they can ask the regional government to report on salient issues in parliament. Increasingly, regional parliaments are trying to receive reports, not only after meetings of the Council of Ministers (e.g. the Belgian Regions), but also before such meetings take place (e.g. the German Länder). As part of such meetings, certain regions are starting to develop strategies for mandating, i.e. for imposing their view on the government and for controlling after Council meetings how their views were represented (Abels, 2015).

Next to the parliament - executive relations within the regional level, regional parliaments can also become involved in controlling national executives. They can engage in scrutiny of national EU policies, formally through second chambers of national parliaments or joint committees, or informally through party links. And if they do so, regional assemblies can act individually (bilaterally) or collectively (multilaterally). Furthermore, the object of their scrutiny activities can be regional EU policy or national EU policy, but also the (domestic) intergovernmental relations through which EU policies are established (Hazell 2010).

Finally, a third (and more informal) way to take part in EU policy-making is to network with other regional parliaments and/or regional governments to gain strength through numbers. The Subsidiarity Monitoring Network of the Committee of the Regions or CALRE - the Conference of European Regional Legislative Assemblies - are examples of such cooperation. In addition, regional parliaments and individual members of regional parliaments can try to engage in informal contacts, for instance based on party affiliation, hence copying the activities of their national colleagues.

Of course, the existence of these different options also means that regional parliaments have a choice of channels and that different parliaments may opt for different strategies. It is an empirical challenge to map the various ways that are exploited by the different regional parliaments throughout the EU. In particular, one has always to bear in mind in this respect that the powers of regional parliaments vary across member states (and sometimes even within member states) and that the options are 
therefore not equally attractive or even at the disposal to all parliaments. Studies of regional parliamentary scrutiny of EU affairs have indeed found substantial variation between parliaments (e.g. Fleischer, 2014, Abels \& Eppler, 2015).

\section{A Research Agenda}

The existing literature on regional parliaments mostly provides us with national perspectives on the institutional strength of just one member state's regional parliaments and their networking practices. The aim of our research agenda is to go beyond that. In trying to answer the question what roles regional parliaments take up in EU policy-making, we raise three inter-connected questions.

The first of these is about what kind of activities regional parliaments deploy in EU politics related to the functions they take up. Are these similar to the ones that they used to take up in their domestic context? Or has the emerging European multilevel context forced regional assemblies to adapt their strategies? Do they behave different from national parliaments? To what extent do they exercise controlling, legislative, and networking functions in the European multilevel polity? And in addition, to what extent can regional parliaments contribute a distinctive regional voice to EU policy-making (Ladrech, 2015)?

Our hypothesis is that the focus of regional parliamentary activities compared to national activities will focus less on influencing legislative outcomes, and more on controlling the local and regional dimension of EU policies, for example implementation issues. This expectation is based on the finding that EU related work of regions (and by extension of regional parliaments) involves a higher share of implementation compared to the national level (Reutter, 2015; Miklin, 2015). As regional elections tend to focus on local or regional issues (except in so far as they are not influenced by the satisfaction with national politics), electoral campaigns and constituency work of regional MPs will be sensitive to EU issues only to the extent to which they have a regional or local dimension.

In addition to the strong implementing role of regional parliaments, certain national specificities further weaken their legislative roles. In the case of Germany, for example, Abels (2015) argues that the regions allowed their legislative competences to be curtailed in return for a stronger role for the Bundesrat. A similar pattern exists in EU affairs, where the Bundesrat plays a much stronger role than the regional parliaments. The Bundesrat is, however, a representation of regional governments, which means that regional parliaments have lost out in the process. In the case of Italy (Nicolini, 2015), but also Austria, there is a tradition, whereby the elaboration of laws relies more on intergovernmental cooperation, with regional parliaments playing a role in the implementation process. In those countries where the Upper House consists of a regional representation (especially Germany and Austria), this 
constitutional set-up may further lead to a division of labour, whereby the Upper House sees itself as the actor responsible for the scrutiny of EU legislative proposals (i.e. including a legislative function), whereas regional parliaments focus on the control of regional governments. Authors 4 and 5 focus on this question - the extent to which regional parliaments focus on controlling their government rather than trying to influence legislation - through analyses of how regional parliaments use mandates and written questions in an EU context. Authors 7 present an in-depth case study of the activities of the Belgian regional parliaments in the context of EU agricultural policy to show that the focus of regional parliaments is indeed on the control of the regional executive rather than attempts to influence the legislative process.

Finally, the question remains to what extent regional assemblies and their individual members embark in contacts with the other players in the European multilevel system. Bursens et al. (2015) report that Belgian regional assemblies, despite being constitutionally empowered with a crucial position in domestic politics, invest only sporadically in contacts with other regional parliaments or with legislatives or executives from other levels, be they national or European. The question of networking is studied both by author 3 (in the context of the EWS), and - in particular - by authors 8 , who analyse institutionalized forms of inter-parliamentary cooperation and the extent to which these networks fulfil legislative or control functions.

A second relevant question is to what extent regional parliaments have been empowered by the Lisbon provisions? In this regard, one must distinguish between direct and indirect effects. As discussed earlier, the direct impact of the EWS and information policies of the EU on the influence of regional parliaments is likely to be relatively small. This has to do with the fact that in most cases these new opportunities are being mediated by national parliaments and that these powers require a considerable amount of capacity and collective action to be effective.

In addition, the EWS can also indirectly empower regional parliaments by motivating them to revise and inform their internal organization and procedures and to take a more active interest in EU politics in general (e.g. Boronska-Hryniewiecka, 2013a). These trends are so far best documented at the national level, where the Lisbon Treaty has affected delegation to parliamentary administrations (Högenauer \& Christiansen, 2015), the organization of committee work (Gattermann et al., 2015) and the amount and nature of interparliamentary cooperation (Hefftler \& Gattermann, 2015). The aim has been to improve the capacity of individual parliaments, as well as their ability to react collectively to European policies. It is still an open question whether the EWS and other treaty provisions have had similar indirect effects on regional assemblies. Did the Lisbon Treaty trigger more interest from regional parliaments in EU politics, e.g. regarding the request for information and the tabling of EU 
files in regional parliamentary committees? Author 2 provides both a detailed conceptualization of 'empowerment' in this context and tests this empirically through several case studies. Authors 6 discuss this question in the context of the adaptation of the German regional parliaments to the Lisbon Treaty.

Finally, regional parliaments are not all equally active or influential, they do not all use the same channels to the same extent and they have been empowered by the Lisbon provisions in different ways and to a different extent. How can we explain the varying levels of empowerment and patterns of activity? If we want to study the multilevel parliamentary system in the EU, we need to empirically grasp the activities of regional parliamentary assemblies and of their members in this multilevel context. One important issue to keep in mind here is the question regarding the level of analysis. Parliamentary behaviour can be examined on an aggregate institutional level, i.e. on parliaments as unitary actors, which has been the most used perspective, or an individual level, which has hardly been used so far (exceptions are Schneider et al., 2014 and Randour and Bursens, 2016). On either level of analysis, we expect substantial variation in the different types of activities we outlined in this paper. The challenge will be to account for this variation. We distinguish three factors that can influence the mobilization and empowerment of regional parliaments.

Firstly, we expect that the strength of regional assemblies varies according to the constitutional position of the assemblies. For instance, the discussion of the EWS has already highlighted the fact that the EWS is implemented in different ways in different countries. Our hypothesis is that the strength of regional parliaments in the domestic coordination of the EWS, and thus the attractiveness of this channel, depends to a large extent on the constitutional position of the region. For example, the Belgian regional parliaments can vote directly in the EWS in policy areas that affect their competences (Bursens et al., 2015; Högenauer et al., 2016). They are not being 'consulted' by the national parliament, but instead their opinions are being forwarded verbatim to the EU institutions. In the UK and Spain, by contrast, regional opinions are considered to be purely consultative. If the national parliament itself does not adopt a reasoned opinion, regional opinions are usually not forwarded to the EU institutions (Vara Arribas, 2015). Secondly, the absence or presence of Eurosceptic parties at the regional level, as well as the state of public opinion affects the demand for parliamentary scrutiny of EU affairs. Raunio (2009) and Ladrech (2015) argue that the presence of Eurosceptic parties backed by a Eurosceptic public generally favour effective scrutiny. In the case of regional parliaments, the Belgian regional parliaments are relatively inactive even though they have a stronger constitutional position than other regional parliaments. Bursens et al. (2015) generally explain this by the low level of salience of EU issues in Belgium. This low political salience is the result of a 
relatively strong pro-European consensus that is not (yet) perturbed by Eurosceptic parties. Thirdly, apart from factors influencing the motivation of parliaments to scrutinize EU issues, there are factors that influence their capacity to do so. Thus, regional parliaments have generally very limited staff resources (Högenauer et al., 2016). The effect of this is that regional parliaments struggle to effectively filter problematic legislative proposals from among the roughly 25.000 legislative documents that the EU sends out every year. They also have limited expertise in the drafting of reasoned opinions while the short deadlines under the EWS further exacerbate these problems. In this context, we expect better-staffed parliaments to be more active than those with more limited resources. However, there are also ways in which regional parliaments can potentially compensate this weakness. In a certain number of cases, regional governments and regional parliaments cooperate in the scrutiny of EU proposals. The Viennese parliament, for example, can use the administration of the executive to get advice on subsidiarity (Miklin, 2015). Similarly, various German Länder governments and the Scottish executive advice their parliaments on subsidiarity (Högenauer et al., 2016; Vara Arribas, 2015). By contrast, the extent of executive-legislative cooperation in Spain is limited (Castellà Andreu \& Kölling, 2015). There is thus further need to examine domestic traditions of cooperation between different actors. Finally, different regional parliaments show different levels of interest in cooperation with other parliaments. One possible factor may once again be the dual or cooperative federalist logic underpinning the set-up of the member state. Thus, cooperation between regional parliaments seems to be relatively low in the UK, Belgium and Spain (Bursens et al., 2015; Högenauer et al., 2016; Castellà Andreau \& Kölling, 2015). Authors 2 use case studies to both illustrate the different degrees to which the EWS has empowered regional parliaments, and explain what causes this variation. Author 3 focuses on mobilization, i.e. the extent to which different regional parliaments and governments have actually used the EWS. She uses quantitative methods to test which factors promote or hinder a high level of activity. Finally, author 4 discusses how the adaptation to the Treaty of Lisbon and the introduction of the EWS have inspired some regional parliaments to try and obtain mandating powers. She further analyses to what extent these attempts have been successful and which factors can explain the differences between regions.

\section{Conclusion}

European integration has created a multilevel political system comprising European, national and regional levels. The resulting governance system has been far more elaborated on the side of the executive than on the side of the legislative. We argued that this unequal development has brought legitimacy issues for the EU. As representation is key to democratic legitimacy, scholars have engaged in studying the role of national and European parliamentary assemblies. The conclusion so far is that 
national parliaments are gradually learning to play the multilevel game and are slowly gaining more formal and informal powers to control national and European executives. Because a growing number of member states is characterized by increasingly relevant regional authorities, the issue of parliamentary representation in the EU, this volume expands to the regional level. Data on regional parliaments' involvement in EU affairs is still very scarce and often anecdotal. The contributions in this issue help to provide a more comprehensive mapping of the activities of regional parliaments and of their individual members. They also add to better theoretically understand the role of regional parliaments in EU legislative and executive policy-making. They moreover examine the way regional parliaments scrutinize EU policies directly at the European level and indirectly at the domestic level by holding regional and national governments accountable during domestic EU policy coordination. Finally, they study the formal and informal information and communication networks regional parliaments build with other legislatives and executives at the different levels of the EU polity. In other words, they make a start analysing a series of analytical and explanatory questions regarding the exact role of regional parliaments and their strength in their domestic environment. The main challenge ahead of us lies in further developing theory-embedded hypotheses to explain variation between regional parliamentary involvement in the multilevel parliamentary system of the EU and to empirically study these in a systematic comparative way.

\section{Bibliography}

Abels, G. (2015). No Longer Losers: Reforming the Germany Länder Parliaments in EU Affairs. In G. Abels and A. Eppler (Eds.), Subnational Parliaments in an EU Multi-Level Parliamentary System: Taking Stock of the Post-Lisbon Era (pp. 193-210). Innsbruck: Studienverlag \& New Jersey: Transaction Publishers.

Abels, G. (2013). Sub-national Parliaments in a Multi-level Parliamentary System - Reform Processes in the German Länder in the Post-Lisbon Era. UACES, Passau, September 3-5, 2013.

Abels, G., \& Eppler, A. (Eds.). (2015). Subnational Parliaments in an EU Multi-level Parliamentary System: Taking Stock of the Post-Lisbon Era. Innsbruck: Studienverlag \& New Jersey: Transaction Publishers. 
Auel, K., \& Christiansen, Th. (2015). After Lisbon. National Parliaments in the European Union. West European Politics, 38(2), 261-281.

Bellamy, R., \& Kröger, S. (2012a). Europe Hits Home - The Domestic Deficits of Representative Democracy in EU Affairs. In T. Evas, U. Liebert \& Ch. Lord (Eds.), Multilayered Representation in the EU (pp. 41-57). Baden Baden: Nomos.

Bellamy, R., \& Kröger, S. (2012b). Domesticating the Democratic Deficit? The Role of National Parliaments and Parties in the EU's System of Governance. Parliamentary Affairs, 68(4), 621-637.

Bellamy, R., \& Kröger, S. (2016). Beyond a Constraining Consensus: The Role of National Parliaments in Domesticating and Normalizing the Politicization of European Integration. Comparative European Politics, 14(2), 125-130.

Boronska-Hryniewiecka, K. (2013a). Democratizing the European multi-level polity? A (re-) assessment of the Early Warning System. Yearbook of Polish European Studies, 16/2013, 123-138.

Boronska-Hryniewiecka, K. (2013b). Subnational Parliaments in EU Policy Control: explaining the variations across Europe. EUI Working Paper, RSCAS 2013/38.

Bursens, P., Maes, F., \& Vileyn, M. (2015). Belgian Assemblies in EU Policy-Making: The More Parliaments, the Less Participation in EU Affairs?' In G. Abels and A. Eppler (Eds.), Subnational Parliaments in an EU Multi-Level Parliamentary System: Taking Stock of the Post-Lisbon Era (pp. 175-192). Innsbruck: Studienverlag \& New Jersey: Transaction Publishers.

Castellà Andreu, J.-M., \& Kölling, M. (2015). Asymmetrical Involvement of Spanish Autonomous Parliaments in EU affairs. In G. Abels and A. Eppler (Eds.), Subnational Parliaments in an EU Multi-Level Parliamentary System: Taking Stock of the Post-Lisbon Era (pp. 269-288). Innsbruck: Studienverlag \& New Jersey: Transaction Publishers. 
Carter, C., \& McLeod, A. (2005). The Scottish Parliament and the European Union: Analysing Regional Parliamentary Engagement. In S. Weatherill \& U. Bernitz (Eds.), The Role of Regions and Subnational Actors in Europe (pp. 67-88). Oxford: Hart Publishing.

Cheneval, F. \& Schimmelfennig, F. (2013). The Case for Demoicracy in the European Union. Journal of Common Market Studies (51)2, 334-350.

Cloots, E., De Baere, G., \& Sottiaux, S. (2012). Federalism in the European Union. Oxford: Hart Publishing.

Cooper, I. (2012). A 'Virtual Third Chamber' for the European Union? National parliaments after the Treaty of Lisbon. West European Politics 35(3), 441-465.

Cooper, I. (2013). Bicameral or Tricameral? National Parliaments and Representative democracy in the European Union. Journal of European Integration 35(5), 531-546.

Corbett, R., Jacobs, F., \& Neville D. (2016). The European Parliament (9 ${ }^{\text {th }}$ ed.). London: John Harper.

Crum, B. (2015). The Emergence of a 'multi-level parliamentary field' - Is there a role for subnational parliaments? In G. Abels and A. Eppler (Eds.), Subnational Parliaments in an EU Multi-Level Parliamentary System: Taking Stock of the Post-Lisbon Era (pp. 63-76). Innsbruck: Studienverlag \& New Jersey: Transaction Publishers.

Crum, B., \& Fossum, J.-E. (2009). The Multilevel Parliamentary Field: a Framework for Theorizing Representative Democracy in the EU. European Political Science Review, 1(2), 249-271.

Crum, B., \& Fossum, J.-E. (2012). A Democratic Backbone for International Organisations: The Multilevel Parliamentary Field. Multilayered Representation in the EU. In T. Evas, U. Liebert \& Ch. Lord (Eds.), Multilayered Representation in the EU (pp. 91-106). Baden Baden: Nomos. 
Fleischer, J. (2014). More scrutiny, more harmony? The Early Warning System and executivelegislative relations at subnational level? 21st International Conference of Europeanists, Washington D.C., 14-16 March 2014.

Follesdal, A., \& Hix, S. (2006). Why there is a Democratic Deficit in the EU. Journal of Common Market Studies, 44(3), 533-562.

Gattermann, K., Högenauer, A.-L., \& Huff, A. (2015). Research Note: Studying a New Phase of Europeanization of National Parliaments, European Political Science, 15(1), 89-107.

Hazell, R., \& Paun, A. (2010). Parliamentary Scrutiny of Multi-Level Governance. In R. Hrbek (Ed.), Legislatures in Federal Systems and Multi-Level Governance (pp. 159-179). Baden Baden: Nomos.

Hefftler, C., \& Gattermann, K. (2015). Interparliamentary Cooperation in the European Union: Patterns, Problems and Potential. In C. Heffler, C. Neuhold, O. Rozenberg, \& J. Smith (Eds.), The Palgrave Handbook on National Parliaments and the European Union (pp. 94-115). London: Palgrave.

Hefftler, C., Neuhold, C., Rozenberg, O., \& Smith, J. (Eds.) (2015). The Palgrave Handbook of National Parliaments and the European Union. London: Palgrave.

Högenauer, A.-L. (2015). The Scottish Parliament - An Active Player in a Multi-level European Union? In G. Abels and A. Eppler (Eds.), Subnational Parliaments in an EU Multi-Level Parliamentary System: Taking Stock of the Post-Lisbon Era (pp. 251-268). Innsbruck: Studienverlag \& New Jersey: Transaction Publishers.

Högenauer, A.-L., \& Christiansen, T. (2015). Parliamentary Administrations in the Scrutiny of EU Decision-making. In C. Heffler, C. Neuhold, O. Rozenberg, \& J. Smith (Eds.), The Palgrave Handbook on National Parliaments and the European Union (pp. 116-132). London: Palgrave.

Högenauer A.-L., Neuhold, C., \& Christiansen, Th. (2016). Parliamentary Administrations in the European Union. London: Palgrave. 
Hurrelmann, A. (2007). Multilevel Legitimacy. Conceptualizing Legitimacy Relationships between the EU and National Democracies. In J. DeBardebeleben \& A. Hurrelmann (Eds.), Democratic Dilemmas of Multilevel Governance (pp. 17-37). London: Palgrave.

Ladrech, R. (2015). Europeanization and Subnational Parliaments - A Research Perspective. In G. Abels and A. Eppler (Eds.), Subnational Parliaments in an EU Multi-Level Parliamentary System: Taking Stock of the Post-Lisbon Era (pp. 77-90). Innsbruck: Studienverlag \& New Jersey: Transaction Publishers.

Lord, C., \& Pollak, J. (2010). The EU's Many Representative Modes: Colliding? Cohering? Journal of European Public Policy 17(1), 117-136.

Maurer, A. (2002). Parlamentarische Demokratie in der Europäischen Union. Der Beitrag des Europäischen Parlaments und der nationalen Parlamente. Baden-Baden, Nomos.

Miklin, E. (2015). Towards a More Active Role in EU Affairs: Austrian State Parliaments after Lisbon, In G. Abels and A. Eppler (Eds.), Subnational Parliaments in an EU Multi-Level Parliamentary System: Taking Stock of the Post-Lisbon Era (pp. 157-174). Innsbruck: Studienverlag \& New Jersey: Transaction Publishers.

Nicolaïdis, K. (2013). European Demoicracy and its Crisis. Journal of Common Market Studies, 51(2), 351-369.

Nicolini, M. (2015), The New Italian Framework for Regional Involvement in EU Affairs: Much Ado and Little Outcomes, In G. Abels and A. Eppler (Eds.), Subnational Parliaments in an EU Multi-Level Parliamentary System: Taking Stock of the Post-Lisbon Era (pp. 233-250). Innsbruck: Studienverlag \& New Jersey: Transaction Publishers.

Puntscher Riekman, S., \& Wudra, D. (2013). Representation in the European State of Emergency: Parliaments against Governments? Journal of European Integration 35(5), 565-582. 
Randour, F., \& Bursens, P. (2016). Slow Adaptors or Active Players? Belgian Regional Parliamentarians and European Affairs after Lisbon. UACES, London, September 4-6, 2013

Raunio, T. (2009). National Parliaments and European Integration: What We Know and Agenda for Future Research, Journal of Legislative Studies, 15(4), 317-334.

Raunio, T. (2011). The Gatekeepers of European Integration? The Functions of National Parliaments in the EU Political System. Journal of European Integration, 33(3), 303-321.

Reutter W. (2015), The Quandary of Representation in Multilevel Systems and German Land Parliaments, In G. Abels and A. Eppler (Eds.), Subnational Parliaments in an EU MultiLevel Parliamentary System: Taking Stock of the Post-Lisbon Era) (pp. 211-232). Innsbruck: Studienverlag \& New Jersey: Transaction Publishers.

Schneider, E., Rittberger, B., \& Wonka, A. (2014). Adapting to Europe? Regional MPs' Involvement in EU Affairs in Germany. Regional and Federal Studies, 24(4), 407-427.

Sprungk, C. (2013). A New Type of Representative Democracy? Reconsidering the Role of National Parliaments in the European Union. Journal of European Integration, 35(5), 547-563.

Sprungk, C. (2016). National Parliaments in the European Union. Comparative European Politics, 14(2), 177-195.

Treib, O. (2014). Implementing and complying with EU governance outputs. Living Review in European Governance, 9, 1. http://europeangovernance-livingreviews.org/Articles/Ireg2014-1.

Vara Arribas, G. (2015), The Early Warning System in Motion: Comparing Different Practices in Subnational Parliaments. In G. Abels and A. Eppler (Eds.), Subnational Parliaments in an EU Multi-Level Parliamentary System: Taking Stock of the Post-Lisbon Era) (pp. 127144). Innsbruck: Studienverlag \& New Jersey: Transaction Publishers. 
Vara Arribas, G., \& Högenauer, A.-L. (2015). Legislative Regions after Lisbon: A New Role for Regional Assemblies In: C. Heffler, C. Neuhold, O. Rozenberg, \& J. Smith (Eds.), The Palgrave Handbook on National Parliaments and the European Union (pp. 133-149). London: Palgrave.

Warleigh, A. (2003). Democracy in the European Union. London, Sage.

Weiler, J. H. H. (2012). In the Face of the Crisis: Input Legitimacy, Output Legitimacy and the Political Messianism of European Integration. Journal of European Integration 34(7), 825-841.

Winzen, Th. (2012). National Parliamentary Control of European Union Affairs: A Crossnational and Longitudinal Comparison. West European Politics, 35(3), 657-672. 